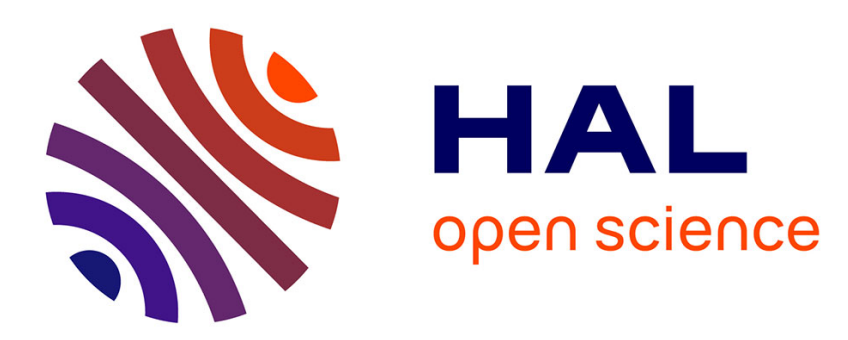

\title{
Rapid determination of the sex of puberal salmonid fish by a technique of immunoagglutination
}

Pierre-Yves Le Bail, Bernard Breton

\section{To cite this version:}

Pierre-Yves Le Bail, Bernard Breton. Rapid determination of the sex of puberal salmonid fish by a technique of immunoagglutination. Aquaculture, 1981, 22, pp.367-375. 10.1016/0044-8486(81)901630 . hal-01600166

\section{HAL Id: hal-01600166 https://hal.science/hal-01600166}

Submitted on 2 Jun 2020

HAL is a multi-disciplinary open access archive for the deposit and dissemination of scientific research documents, whether they are published or not. The documents may come from teaching and research institutions in France or abroad, or from public or private research centers.
L'archive ouverte pluridisciplinaire HAL, est destinée au dépôt et à la diffusion de documents scientifiques de niveau recherche, publiés ou non, émanant des établissements d'enseignement et de recherche français ou étrangers, des laboratoires publics ou privés.

\section{다(1)(2)}

Distributed under a Creative Commons Attribution - ShareAlikel 4.0 International 


\title{
RAPID DETERMINATION OF THE SEX OF PUBERAL SALMONID FISH BY A TECHNIQUE OF IMMUNOAGGLUTINATION
}

\author{
P.Y. LE BAIL and B. BRETON \\ Laboratoire de Physiologie des Poissons, I.N.R.A., Campus de Beaulieu, 35042 - Rennes- \\ Cedex (France)
}

(Accepted 20 May 1980)

\begin{abstract}
Le Bail, P.Y. and Breton, B., 1981. Rapid determination of the sex of puberal salmonid fish by a technique of immunoagglutination. Aquaculture, 22: 367-375.

The present study describes a rapid, simple and specific method to determine the sex of salmonid fish. This method is based on the detection by immunoagglutination of the serum vitellogenin of females in which oocy tes are undergoing vitellogenesis. The application of this technique demonstrated the possibility of detecting vitellogenin in female brown trout as early as April and in all female Atlantic salmon captured in Brittany during the fishing season, between March and June.
\end{abstract}

\section{INTRODUCTION}

A means of determining the sex of salmonid fish, without injuring the animal, has been sought by ecologists in order to determine the reproductive potential of the populations. Moreover, the application of such a technique would enable us to optimize the administration of stocks of breeders destined for fish farming.

Outside the reproductive period, the research of criteria for the determination of sex based upon morphological characteristics is a long and difficult process. However, it is possible to envisage a sexing technique based on the biochemical recognition of a specific protein in one of the sexes.

As early as 1932, Sasaki proposed a means of recognizing the sex of chickens by using as a criterion the presence of a plasmatic protein which is the forerunner of the vitellin reserves of the egg. More recently, an equivalent protein (vitellogenin) has been demonstrated in salmon: $O$. nerka (Ridgway et al., 1962), O. kisutch (Vanstone and Chung-Wai Ho, 1961), O. keta and O. masou (Yoneda and Ishihara, 1973), S. salar (Fine and Drilhon, 1963); and in the trout: S. gairdneri (Thurston, 1967), using techniques of electrophoresis and immunodiffusion. Although sufficiently sensitive to permit the detection of vitellogenin during the annual cycle (Gronlund et al., 1971), the difficulty of putting the above-mentioned techniques into practice does not allow us to consider them likely to provide immediate results to prospective practitioners. 
The object of this study was to discover a simple, specific and immediate method of immunological identification of vitellogenin.

\section{MATERIAL AND METHODS}

Perfecting the sexing technique

\section{Purification of the vitellogenin}

In salmonid fish the oestrogenization of the male and of the female at any stage of the reproductive cycle induces an hepatic synthesis of vitellogenin and an increase in the plasmatic concentration of this protein (Bailey, 1957; Takashima et al., 1972). This method was applied to female rainbow trout which were treated with oestradiol- $17 \beta$ by intra-peritoneal injection during a period of 4 weeks, at the rate of $0.5 \mathrm{mg} / \mathrm{kg}$ every 2 days. At the end of the treatment, the animals were killed and the blood collected from the caudal artery. The purification of the vitellogenin is inspired by the technique of Hara and Hirai (1978). After coagulation the serum is separated by centrifugation and left to dialyse for 3 days against 100 volumes of distilled water, renewed each day. The precipitate which forms is separated by centrifugation $\left(3000 \mathrm{~g}, 4^{\circ} \mathrm{C}, 1 \mathrm{~h}\right)$. The residue is redissolved in a Tris $0.05 \mathrm{M} \mathrm{NaCl} 1 \mathrm{M}$ $\mathrm{pH} 9.2$ buffer. The insoluble substance is eliminated by centrifugation. The supernatant is deposited on a column of sepharose $6 \mathrm{~B}(1 \mathrm{~m} \times 1.6 \mathrm{~cm})$.

The recognition of the vitellogenin in the fractions issuing from the chromatography was made by electrophoresis on a gel of polyacrylamide at $5 \%$ (14 cm long) according to the technique of Davis (1964), modified by readjusting the $\mathrm{pH}$ of the migrating buffer to 9.2 by $1 \mathrm{~N} \mathrm{NaOH}$. Sera of females undergoing vitellogenesis and those of males are used as a reference. The richest fractions are put together and dialysed against distilled water. The precipitate is returned to the Tris $0.05 \mathrm{M} \mathrm{NaCl} 1 M \mathrm{pH} 9.2$ buffer, then rechromatographed on sepharose $6 \mathrm{~B}$ and dialysed in the same conditions as before. The concentration of the final solution of vitellogenin (VgP) was determined by the method of Lowry et al. (1951).

\section{Preparation of the anti-sera $(A V g P)$}

The anti-sera were produced in rabbits by subcutaneous injection of $0.5 \mathrm{mg}$ of $\mathrm{VgP}$ accompanied by a complete Freund adjuvent, at a rate of one injection every 2 weeks during a period of 3 months. After this period the animals were bled and the anti-VgP $\gamma$-globulins were isolated from the serum by precipitation in ammonium sulphate at $33 \%$ saturation.

The agglutination test

We used MacCarthy's (1975) technique of sensitization of latex particles, in which the glycine $\mathrm{NaCl}$ buffer was replaced by a veronal $0.1 \mathrm{M}$ buffer at pH 8.2. The latex particles used were DIFCO balls 0.81 . They were sensitized 
in the same conditions as those described by MacCarthy in solutions containing AVgP $\gamma$-globulins at concentrations four and nine times superior to those of the serum $\gamma$-globulins. The agglutination reaction is effected by placing, on a clean glass slide, a drop from the sample to be tested, a drop of veronal buffer and a drop of the suspension of sensitized particles. This mixture is homogenized and shaken slowly. The positive reaction, characterized by the appearance of conglomerations of particles, develops in 2-3 min.

\section{Validation of the test}

\section{Immunodiffusion}

The validation of the positive reactions to the agglutination test was investigated by immunodiffusion on a gel of agarose at $0.8 \%$ in a veronal $0.05 \mathrm{M}$ pH 8.3 buffer.

The search for vitellogenin in fish previously sexed by observation of the gonads

This was carried out on two species.

Brown trout (Salmo trutta fario). Male and female trout (originating from the Vermenoux fish-farm) were killed monthly during the first reproductive cycle. The female stages were characterized either by the gonado-somatic index (GSI) or by the precise stage and the diameter of the oocytes during the final phases of the cycle, according to the criteria defined by Jalabert (1978): end of vitellogenesis (EV), maturing, ovulated. Plasma from each fish was obtained after drainage of blood before killing. This plasma was preserved frozen until the test.

Atlantic salmon (Salmo salar). The fish were from catches made by anglers during the whole period of legal fishing over two stretches of water off the Brittany coast: the Elorn and the Penze. The total amount of blood was frozen on the spot, and the serum was not separated by centrifugation until after its arrival at the laboratory. The female stages were characterized by the gonadosomatic index and by the average diameter of the oocytes, calculated from 48 oocytes taken over six different ovigerous folds.

\section{RESULTS}

A typical picture of the reaction to agglutination is shown in Fig. 1.

Sensitivity of the tests

The limit of the ranges of agglutination as a function of the concentration in vitellogenin is shown in Table $I$. The agglutination reaction can occur only in a range of "équivalence" concentrations. The table shows that to two con- 


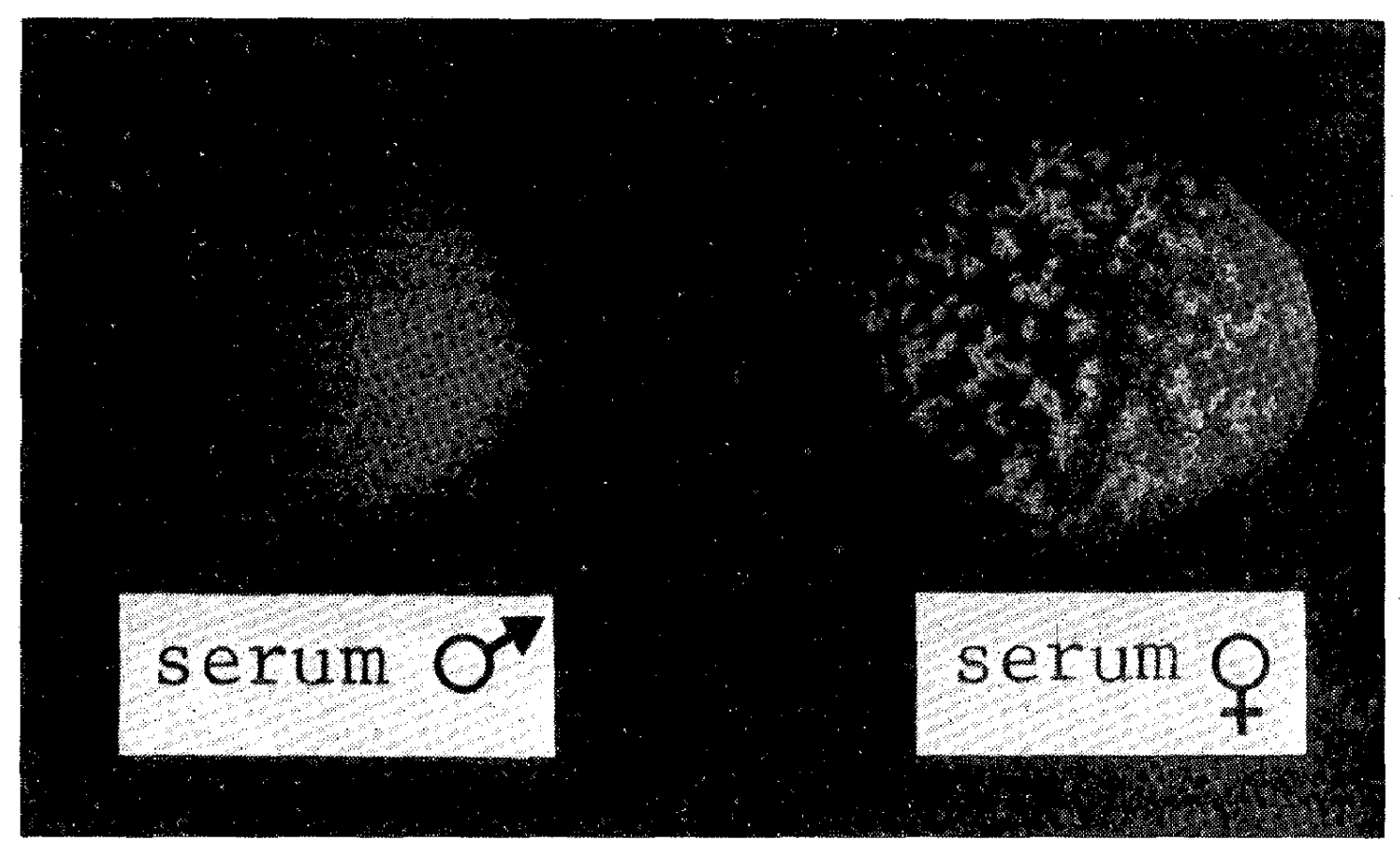

Fig. 1. Antivitellogenin latex test. Female serum induces agglutination.

\section{TABLE I}

Response zone of immunoagglutination and immunodiffusion vitellogenin tests

\begin{tabular}{llllllllllllll}
\hline Test & \multicolumn{10}{c}{ Vitellogenin $(\mathrm{mg} / \mathrm{ml})$} \\
& 120 & 60 & 30 & 15 & 8 & 4 & 2 & 1 & 0.5 & 0.25 & 0.1 & 0.05 \\
\hline $\begin{array}{l}\text { Immunoagglutination } \\
\times 9^{1} \\
\times 4^{1}\end{array}$ & - & - & $(+)$ & + & + & + & + & $(+)$ & - & - & - & - \\
$\begin{array}{l}\text { Immunodiffusion } \\
\text { original antiserum }\end{array}$ & - & - & - & $(+)$ & + & ++ & + & + & $(+)$ & - & - \\
\hline
\end{tabular}

+ , Positive reaction; - , negative reaction; $(+)$, limited reaction.

$1 \times 9, \times 4$ : latex particles sensitized with $\gamma$-globulin nine and four times more concentrated than original anti-serum.

centrations of $\mathrm{AVgP}$ sensitization two different ranges of vitellogenin concentration correspond, leading to positive results. The sensitivity of results in ranges of weak concentration in vitellogenin is increased by reducing the quantity of sensitizing antibodies.

At both extremes of the range of reaction, a negative response can be due either to an excess, causing saturation of the antibody, or to the presence of only small concentrations or complete absence of vitellogenin. In these conditions a new negative reaction, brought about by the addition to the reactive sample of a serum known to bring about agglutination, shows, in effect, the 
presence of a large amount of vitellogenin and permits us to decide between the two hypotheses (Table II). Immunodiffusion appears less sensitive, but its range of positive responses is much wider towards the high concentrations. In all cases, when the concentration of plasma vitellogenin is too high to allow a positive reaction using total serum, dilution of the serum could result in a positive reaction.

TABLE II

Presence of vitellogenin during the annual cycle of brown trout

\begin{tabular}{|c|c|c|c|c|c|c|c|c|}
\hline \multirow[t]{3}{*}{ Animal } & \multirow[t]{3}{*}{ Date } & \multirow{3}{*}{$\begin{array}{l}\text { GSI } \\
(\bar{X} \pm \sigma)\end{array}$} & \multirow{3}{*}{$\begin{array}{l}\phi \bar{W} \\
(\bar{X} \pm \sigma)\end{array}$} & \multirow[t]{3}{*}{ Stage } & \multicolumn{4}{|c|}{ Antibody concentration (AVgP) } \\
\hline & & & & & $\times 9$ & $\times 9$ & $\times 4$ & $\times 4+0^{+}$ \\
\hline & & & & & $1 / 5$ Serum & $\begin{array}{l}\text { Total } \\
\text { Serum }\end{array}$ & $\begin{array}{l}\text { Total } \\
\text { Serum }\end{array}$ & $\begin{array}{l}\text { Total } \\
\text { Serum }\end{array}$ \\
\hline 5 & 02.11 .1976 & $14.54 \pm 1.34$ & $4.27 \pm 0.12$ & EV & $+(1)$ & $+(4)$ & & \\
\hline 5 & 16.11 .1976 & $15.04 \pm 2.02$ & $4.40 \pm 0.14$ & EV & & $+(5)$ & & \\
\hline 6 & 30.11 .1976 & $17.16 \pm 2.26$ & $4,90 \pm 0.15$ & EV & & $+(6)$ & & \\
\hline 5 & 13.12 .1976 & $16.36 \pm 3.19$ & $4.43 \pm 0.11$ & Maturing & & $+(5)$ & & \\
\hline 5 & 13.01 .1977 & $1.61 \pm 0.23$ & 1 & Ovulation & & $+(3)$ & $-(2)$ & $+(2)$ \\
\hline 5 & 10.02 .1977 & $0.87 \pm 0.31$ & 1 & Post-ovu. & & $+(1)$ & $+(1)$ & \\
\hline 5 & 18.03 .1977 & $0.85 \pm 0.15$ & 1 &.$\Xi$ & & & $\begin{array}{l}-(3) \\
-(5)\end{array}$ & $\begin{array}{l}+(3) \\
+(5)\end{array}$ \\
\hline 5 & 12.04 .1977 & $0.85 \pm 0.15$ & 1 & $\frac{n}{6}$ & & $+(2)$ & $-(3)$ & $+(3)$ \\
\hline 5 & 12.05 .1977 & $0.56 \pm 0.40$ & 1 & $\stackrel{ \pm}{\$}$ & & $+(2)$ & $-(3)$ & $+(3)$ \\
\hline 5 & 26.05 .1977 & $1.02 \pm 0.28$ & $\overline{1}$ & 焉 & & $+(5)$ & & \\
\hline 5 & 17.06 .1977 & $1.17 \pm 0.26$ & $1.25 \pm 0.18$ & 용 & & $+(5)$ & & \\
\hline 5 & 20.07 .1977 & $2.56 \pm 0.45$ & $2.06 \pm 0.33$ & 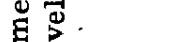 & & $+(5)$ & & \\
\hline 5 & 18.08 .1977 & $3.81 \pm 1.29$ & $2.64 \pm 0.42$ & 露? & $+(2)$ & $+(3)$ & & \\
\hline 5 & 14.09 .1977 & $10.46 \pm 2.45$ & $3.89 \pm 0.40$ & & $+(3)$ & $+(2)$ & & \\
\hline 4 & 13.10 .1977 & $14.21 \pm 2.70$ & $4.43 \pm 0.15$ & EV & $+(3)$ & & $-(1)$ & $+(1)$ \\
\hline 4 & 25.10 .1977 & $17.39 \pm 3.40$ & $4.45 \pm 0.26$ & EV & $+(4)$ & & & \\
\hline
\end{tabular}

GSI, gonado-somatic index $(\%) ; \phi W$, oocyte diameter $\digamma^{+}$, positive female serum; $(n)$, no. of responses; $\mathrm{EV}$, end of vitellogenisis.

\section{Application}

Detection of vitellogenin during the reproductive cycle of the brown trout At no stage of the cycle was a positive reaction obtained from male sera. In contrast, in the female (Table II) the appearance of vitellogenin could be detected in certain animals from 12 April and became a general feature on 26 May, when the phase of rapid growth of the gonad and the oocytes had not begun. During a period of 1 or 2 months after ovulation no positive reaction was obtained. In a larger sample, the immunodiffusion test confirmed that all females possess circulating vitellogenin from approximately mid-May (56/56), when males (33/33) give negative responses.

\section{The case of Atlantic salmon}

The catches were spread out between the end of March and the end of June, at which period no secondary sexual characteristic enables differentiation between the sexes. 
Vitellogenin was detected in all females by immunoagglutination, while the GSI were low and the diameters of the oocytes did not vary noticeably during the fishing season. No positive reaction was obtained from any of the male fish (Table III).

The collection of blood samples, although carried out in poor conditions (the freezing of the total amount of blood caused, among other things, considerable haemolysis), does not seem to affect the result.

\section{TABLE III}

Presence of vitellogenin detected with the agglutination test in salmon serum during the angling season in Brittany

\begin{tabular}{|c|c|c|c|c|c|}
\hline \multicolumn{2}{|c|}{ Date of capture } & \multirow[t]{2}{*}{ GSI } & \multirow[t]{2}{*}{$\phi \mathrm{W}$} & \multirow{2}{*}{$\begin{array}{l}\text { Vitèllogenin } \\
\text { presence }\end{array}$} & \multirow[t]{2}{*}{ Sex } \\
\hline Month & Day & & & & \\
\hline \multirow[t]{12}{*}{ March } & 03 & & & - & o \\
\hline & 03 & 0.75 & 1.60 & + & প \\
\hline & 03 & 0.90 & 1.72 & + & $q$ \\
\hline & 06 & 0.83 & 1.67 & + & $q$ \\
\hline & 08 & 0.76 & 1.62 & + & $\varsubsetneqq$ \\
\hline & 17 & 1.59 & 1.99 & + & $q$ \\
\hline & 17 & 0.95 & 1.88 & + & \% \\
\hline & 17 & & & - & $d$ \\
\hline & 25 & 1.30 & 2.08 & + & \% \\
\hline & 26 & & & - & 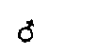 \\
\hline & 30 & 0.67 & 1.62 & + & \& \\
\hline & & 0.94 & 1.81 & + & \% \\
\hline \multirow[t]{12}{*}{ April } & 01 & 0.88 & 1.78 & + & q \\
\hline & 01 & 1.37 & 1.88 & + & 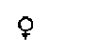 \\
\hline & 03 & 1.14 & 1.88 & + & \\
\hline & 06 & 0.74 & 1.65 & + & ९ \\
\hline & 15 & 0.87 & 1.66 & + & q \\
\hline & 18 & 0.92 & 1.68 & + & 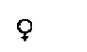 \\
\hline & 18 & 1.30 & 1.91 & + & q \\
\hline & 21 & & & - & d \\
\hline & 25 & & & - & $\delta$ \\
\hline & 28 & 0.91 & 1.80 & + & q \\
\hline & 30 & 1.03 & 1.78 & + & 甲 \\
\hline & & 0.57 & 1.51 & + & q \\
\hline \multirow[t]{4}{*}{ May } & 03 & 1.22 & 1.91 & + & q \\
\hline & 20 & 1.12 & 1.84 & + & \% \\
\hline & 31 & 1.71 & 2.24 & + & 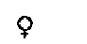 \\
\hline & 31 & & & - & $\delta$ \\
\hline \multirow[t]{2}{*}{ June } & 04 & 1.09 & 1.88 & + & $q$ \\
\hline & 10 & & & - & $d$ \\
\hline
\end{tabular}




\section{DISCUSSION}

This study has permitted the perfection of a method of immunological detection of plasmatic vitellogenin in salmonid fish and, as a consequence, the definition of a sex test of a simple nature.

The study, carried out during a complete reproductive cycle of the brown trout, shows that the sensitivity of the immunoagglutination test allows the qualitative detection of vitellogenin as early as April. Between April and May, although a degree of uncertainty in the sexing exists, doubtless due to the asynchronous beginning of vitellogenesis, the use of this test enables one to judge the proportion of female breeders in fish-farm stocks 5 or 6 months before the appearance of the morphological characteristics generally used in sex determination.

In the realm of population dynamics, this test constitutes a tool for the estimation of the number of females undergoing vitellogenesis and, consequently, of the reproductive potential for a given population in a given sector.

The study by Gronlund et al. (1971) on the sockeye salmon (O. nerka) shows that it is possible to detect vitellogenin as early as January in saltwater fish. Fine and Drilhon (1964), during the course of a less systematic study on the Atlantic salmon (S. salar), noted the presence of vitellogenin in females at different stages: when they come upstream and on the spawning ground. Our results tend the same way despite small GSI values $(<2 \%)$. All the females caught between March and the middle of June show a positive result, which leads us to suppose that the process of vitellogenesis begins at the moment of entry into fresh water. The implementation of this technique at the level of fish traps would, in these conditions, be strongly indicated in order to determine the sex ratio and the reproductive potential of a population of salmon.

The concentration of sensitizing antibodies permitted us to obtain limits of detection, compatible with the amount of circulating vitellogenin, in most of the animals undergoing vitellogenesis. Greater sensitivity could be obtained by reducing the quantity of antibodies fixed on the latex particles. These conditions ought to enable us to extend the range of positive reactions towards the weak concentrations of vitellogenin, and to increase the percentage of sexing at the beginning of the cycle. It is, however, necessary to state that the more sensitive the test, the more the reaction time increases, and the reading is less clear. Thus, the definition of optimum concentrations of sensitizing. antibodies and particles will depend on each individual case studied.

On a more fundamental level, the use of this test has allowed us to show that, contrary to what has been suggested and shown in certain species of salmonid, brown trout (Crim and Idler, 1978) and rainbow trout (Whitehead et al., 1978), the serum vitellogenin appears from April and not in July. This fact demonstrates the beginning of vitellogenin synthesis. The incorporation, from this period, of vitellogenin in the eggs has yet to be shown.

The presence of vitellogenin in the blood after ovulation does not necessarily imply its hepatical synthesis. Wallace and Jared (1968) showed that in the 
male Xenopus laevis or in the ovariectomised female of the same species, the halflife of this protein is approximately 40 days. An equivalent hypothesis can be envisaged in the ovulated trout.

\section{ACKNOWLEDGEMENTS}

The authors would like to thank P. Prouzet (C.O.B.), the Finistère Association of Anglers, the Shupen Association of Elorn and all the anglers who participated in the collection of samples, and also E. Sambroni for her technical assistance. This work is the result of research sponsored by the "Ministère de la qualité de la vie" (convention no. 65/1327), and by the C.N.E.X.O. (convention no. $77 / 1619$ ).

\section{REFERENCES}

Bailey, R.E., 1957. The effect of estradiol on serum calcium, phosphorus, and protein of Goldfish. J. Exp. Zool., 136: 455-469.

Crim, L.W. and Idler, D.R., 1978. Plasma gonadotropin, estradiol and vitellogenin and gonad phosvitin levels in relation to the seasonal reproductive cycles of female brown trout. Ann. Biol. Anim. Biochim. Biophys., 18(4): 1001-1005.

Davis, B.J., 1964. Disc electrophoresis. II: Method and application to human serum proteins. Ann. N.Y. Acad. Sci., (121): 404-427.

Fine, J.M. and Drilhon, A., 1963. Etude immunologique des proteines du sérum de Salmo salar: étude par immunodiffusion. C.R. Soc. Biol., 157: 1937-1940.

Fine, J.M. and Drilhon, A., 1964. Etude électrophorétique et immunologique des proteines sériques de quelques espèces de Salmonidés. C.R. Soc. Biol., 157: 1307-1310.

Gronlund, W.D., Hodgins, H.O. and Blood, E.A., 1971. Pituitary gonadotrophic activity and ovarian antigens for predicting age at maturity of high seas Sockeye salmon. I. N.P.F.C., Annu. Rep., pp. 101-107.

Hara, A. and Hirai, H., 1978. Comparative studies on immunochemical properties of femalespecific serum protein and egg yolk proteins in rainbow trout (S. gairdneri). Comp. Biochem. Physiol., 59 B: 339-343.

Jalabert, B., 1978. Production of fertilizable oocytes from follicles of rainbow trout (S. gairdneri) following in vitro maturation and ovulation. Ann. Biol. Anim. Biochim. Biophys., 18 (2B): 461-470.

Lowry, O.H., Rosenbrough, N.S., Farr, A.L. and Randall, R.S., 1951. Protein measurement with folin phenol reagent. J. Biol. Chem., 193: 265-275.

MacCarthy, D.H., 1975. Detection of Aeromonas salmonicida antigen in diseased fish tissue. J. Gen. Microbiol., 88: 384-386.

Ridgway, G.J., Klontz, G.W. and Matsumoto, C., 1962. Intraspecific differences in serum antigens of red salmon demonstrated by immunochemical methods. I.N.P.F.C., Annu. Rep., 8: 1-13.

Sasaki, K., 1932. Precipitation test for the sexes of fowl blood serum with special reference to egg-laying. J. Im munol., 23 (1): 1-10.

Takashima, F., Hibiya, T., Phan-Van-Ngan and Aida, K., 1972. Endocrinological studies on lipid metabolism in rainbow trout. II: Effects of sex steroids, thyroid powder and adrenocorticotropin on plasma lipid content. Bull. Jpn. Soc. Sci. Fish., 38(1): 43-49.

Thurston, R.V., 1967. Electrophoretic patterns of blood serum proteins from rainbow trout (S. gairdneri). J. Fish. Res. Board Can., 24(10): 2169-2188.

Vanstone, W.E. and Chung-Wai Ho, F, 1961. Plasma proteins of coho salmon (O. kisutch) as separated by zone electrophoresis. J. Fish. Res. Board Can., 18(3): 393-399. 
Wallace, R.A. and Jared, D.W., 1968. Studies on amphibian yolk. VII: serum phosphoprotein synthesis by vitellogenic females and estrogen-treated males of Xenopus laevis. Can. J. Biochem., 46: 953-960.

Whitehead, C., Bromage, N.R. and Forster, J.R., 1978. Seasonal changes in reproductive function of the rainbow trout (Salmo gairdneri). J. Fish Biol., 12: 601-608.

Yoneda, T. and Ishihara, Y., 1973. Disc electrophoretic patterns of the blood serum proteins from chum salmon (O. keta) and cherry salmon (O. masou). Bull. Fac. Fish., Hokkaido Univ., 24 (2): 76-89.

\section{RESUME}

Le Bail, P.Y.. et Breton, B., 1981. Détermination rapide du sexe des salmonidés pubères par une technique d'immunoagglutination. Aquaculture, 22:367-375 (en anglais).

Ce travail décrit un test de sexage des Salmonidés, rapide, simple et spécifique. Cette méthode est basée sur la détection, par immunoagglutination, de la vitellogenine serique présente chez la femelle en cours de vitellogénèse. L'application de cette technique a montré qu'il était possible de détecter de la vitellogénine chez la truite fario d'élevages dès le mois d'Arril et chez toutes les femelles de Saumon atlantique capturées en Bretagne au cours de la saison de pêche sportive s'étendant du mois de Mars au mois de Juin. 